\title{
DEVELOPMENT OF INORGANIC CHEMISTRY OF TRANSITIONAL CHEMISTRY MATERIALS IN CHEMISTRY DEPARTMENT
}

\author{
Dina Kartika Maharani $^{1 *}$, Kusumawati Dwiningsih ${ }^{1}$, Rusly Hidayah ${ }^{1}$ \\ ${ }^{1}$ Kimia, FMIPA, Universitas Negeri Surabaya \\ *Corresponding author: dinakartika@unesa.ac.id
}

\begin{abstract}
Learning materials have been developed in inorganic chemistry elements of transition elements have been developed online. The flow of the development model suggested by Thiagarajan, Semmel, and Semmel is 4-D (four D Models). This model consists of 4 stages of development, namely Define, Design, Develop, and Disseminate, but in this study it is limited to the develop stage. Based on the results of observations of student activities and student response questionnaires, it can be concluded that the material in the Inorganic Chemistry of the Transition Element is feasible
\end{abstract}

Keywords: Vi-learn, Inorganic Chemistry, Transition Elements

\section{PENDAHULUAN}

Materi kimia anorganik unsur transisi merupakan salah satu materi pokok yang terdapat dalam mata pelajaran kimia unsur. Karakteristik materi kimia unsur dianggap abstrak karena didalamnya mencakup makroskopis, mikroskopis, dan simbolis. Representasi makroskopis menunjukkan fenomena-fenomena yang terjadi dalam kehidupan sehari-hari maupun yang dipelajari di laboratorium terkait unsur dan senyawanya menjadi suatu bentuk makro yang bisa diamati langsung. Aspek mikroskopis merupakan representasi yang memiliki tingkatan untuk menjelaskan dan menerangkan fenomena yang diamati sehingga menjadi sesuatu yang dapat dipahami, misalnya pergerakan elektron, molekul, atau atom. Pada tingkat mikroskopis ini lebih menekankan pada partikel dan sifatnya. Aspek simbolis digunakan untuk mewakili fenomena makroskopis dengan menggunakan persamaan kimia, persamaan matematika, grafik dan mekanisme reaksi. Ketiga aspek tersebut saling terkait satu sama lain [1]. Karakteristik materi kimia anorganik unsur transisi yang memenuhi ketiga aspek tersebut, sehingga siswa atau mahasiswa memerlukan bantuan media belajar interakstif berupa video atau gambar untuk dipelajari secara detail. Oleh karena itu dibutuhkan pembelajaran salah satunya melalui tugas-tugas dalam kuliah daring yang menfasilitasi mahasiswa untuk belajar melalui video atau gambar dengan lebih mandiri dan jelas. Pemahaman yang lebih kuat mengenai kimia unsur transisi melalui video dan gambar diharapkan berdampak terhadap meningkatnya hasil belajar. Perkembangan pada sektor teknologi informasi dan komunikasi yang berkembang secara pesat tersebut menawarkan hal-hal yang baru bagi dunia pendidikan misalnya e-learning. Pembelajaran dengan pemanfaatan elearning diyakini dapat meningkatkan kualitas pembelajaran. Akan tetapi pemanfaatan e-learning kurang maksimal karena lemahnya kualitas dan kontrol terhadap metode pendidikan e-learning seperti belum mampunya mahasiswa mengelola waktu dan memproses informasi secara mandiri menjadi permasalahan tersendiri bagi penyelenggara pendidikan e-learning [2].

Salah satu bentuk mengatasi hal tersebut perlu dibuat tujuan pembelajaran yang dapat dicapai oleh mahasiswa yaitu dengan adanya inovasi dalam 
pembelajaran yang dapat mengoptimalkan proses belajar mahasiswa dari segi waktu dan kebebasan dalam memperoleh informasi yang dapat dilakukan yaitu dengan menambah jam belajar secara online.Bentuk-bentuk komunikasi berbasis internet seperti blog, forum diskusi (bulletin board), social networking, instant messaging dan e-mail telah menjadi media/alat komunikasi sehari-hari yang sering digunakan. Media dengan sentuhan teknologi informasi akan melahirkan konsep E-learning yang memiliki karakteristik dapat digunakan oleh siapa saja (everyone), dimana saja (everywhere), dan kapan saja (everytime) sehingga memiliki peran yang signifikan pada perluasan kesempatan belajar [3].

E-learning atau electronic learning merupakan suatu proses perkembangan teknologi yang diaplikasikan dalam hal penyampaian pengetahuan dalam proses belajar mengajar. E-learning kini semakin dikenal sebagai salah satu cara untuk mengatasi masalah pendidikan, baik di negara-negara maju maupun di negara yang sedang berkembang seperti Indonesia [2].

Berdasarkan fakta tersebut, multimedia interaktif yang berbasis blended learning dapat dijadikan alternatif sebagai inovasi dalam proses pembelajaran serta diharapkan dapat menunjang pencapaian hasil belajar pada mata kuliah kimia anorganik transisi.

Dalam penelitian ini akan dikaji bagaimana kelayakan perangkat pembelajaran kimia anorganik transisi dari aspekaktivitas dan respon mahasiswa.

\section{METODE}

Obyek dalam penelitian ini adalah perangkatpembelajarankimia anorganik transisi.

Perangkatpembelajarankimia

anorganik transisi inimengikutialur model pengembanganyang disarankan oleh Thiagarajan, Semmel, dan Semmel [4]yaitu4-D (four D Models). Model ini terdiri dari 4 tahap pengembangan yaitu Define, Design, Develop, dan Disseminate, namundalampenelitianinidibatasisampaita hapdevelop.

\section{Teknik Analisis Data}

Teknik analisis data dilakukan secara deskriptif kuantitatif perangkat pembelajaran kimia anorganik transisidikatakan layak bila persentase lebih dari $61 \%$ [5].

1. Analisis Data Observasi Aktivitas Mahasiswa

Aktivitas mahasiswa yang berkaitan dengan multimedia interaktif yang pelaksanaannya dilakukan baik secara online maupun offline diamati dan dicatat oleh pengamat dan peneliti pada lembar observasi aktivitas mahasiswa. data pengamatan yang diperoleh kemudian diolah dalam bentuk persentase dengan persamaan berikut:

$$
P=\frac{A}{N} x 100 \%
$$

Keterangan :

$$
\begin{aligned}
& \mathrm{P}=\text { Persentase } \\
& \mathrm{A}=\text { Jumlah skor hasil } \\
& \text { pengumpulan data } \\
& \mathrm{N}=\text { Skor kriteria }
\end{aligned}
$$

(adaptasi dari Riduwan, 2005)

Dikatakan layak jika dari semua aspek dalam lembar observasi aktivitas mendapatkan persentase $\geq 61 \%$ dengan kriteria layak dan sangat layak.

2. Analisis Data Respon Mahasiswa

Lembar respon mahasiswa diisi langsung oleh mahasiswa diberikan setelah proses pembelajaran yang bertujuan untuk menganalisis jawaban atau tanggapan responden dan diperoleh berdasarkan perhitungan skala Guttman.

Hasil lembar respon mahasiswa dalam penelitian ini dikatakan layak dan sangat layak apabila persentase $\geq 61 \%$.

\section{HASIL DAN PEMBAHASAN}

\section{Tahap Pendefinisian (Define)}

Analisis ujung depan mempunyai tujuan untuk memunculkan permasalahan. Permasalahan yang dimunculkan dalam 
penelitian yaitu ditunjukkan dengan adanya data empirik melalui penyelidikan. Sedangkan pengumpulan data dilakukan dengan menggunakan studi literatur dan studi lapangan yaitu melalui observasi lapangan dan penyebaran angket. Penyelidikan dilakukan dengan melihat hasil observasi yang berkaitan dengan kondisi lapangan tersebut. Perihal yang menjadi pertimbangan pada analisis ujung depan adalah RPS (Rencana Pembelajaran Semester) mata kuliah Kimia Anorganik Unsur Transisi yang berlaku di Jurusan Kimia Unesa, teori belajar dan tuntutan mahasiswa dimasa depan.

Ditinjau dari segi usia mahasiswa dimana pada umumnya mahasiswa yang menempuh mata kuliah kimia anorganik unsur transisi memasuki tahapan operasional formal. Menurut Jean Piaget, pada tahapan ini perkembangan intelektual, mahasiswa umumnya terjadi dengan melewati tahapan-tahapan yang berurutan dan berkesinambungan seperti mahasiswa memiliki kemampuan dalam mengkoordinaasikan kemampuan kognitifnya seperti berpikir secara abstrak, menalar secara logis, dan menarik kesimpulan dari informasi yang tersedia [6].

Ditinjau dari latar belakang keluarga, sosial, budaya, dan ekonomi pada mahasiswa. Umumnya mahasiswa yang berasal dari keluarga yang mampu tentunya mereka akan memiliki fasilitas serta sarana yang cukup untuk menunjang prsoses belajarnya. Berdasarkan hasil pengamatan yang dilakukan diperoleh bahwa mahasiswa memiliki sarana dan prasarana untuk menunjang prsoses belajarnya terbilang memadai dapat dilihat dari kebanyakan mahasiswa menggunakan laptop maupun notebook dalam belajarnya

Analisis tugas dilakukan untuk menyusun isi materi ajar secara garis besar. Tujuannya menentukan kemampuan mahasiswa dalam memahami materi ajar serta mengevaluasi kemampuan mahasiswa dalam menyelesaikan tugas.
Analisis ini dilakukan dengan merinci isi media ajar yang diperoleh berdasarkan capaian pembelajaran serta kemampuan akhir pada RPS (Rencana Pembelajaran Semester) mata kuliah Kimia Anorganik unsur transisi yang berlaku di Jurusan Kimia. Berdasarkan RPS. Capaian pembelajaran secara garis besar, meliputi:Memahami konsep-konsep dasar ekstraksi logam, sifat-sifat fisika dan kimia unsur dan senyawa transisi deret pertama, kedua, dan ketiga blok d

Analisis konsep dilakukan untuk mengidentifikasi konsep yang diajarkan. Konsep yang diajarkan adalah konsep yang berkaitan dengan unsur transisi. Analisis konsep dapat dilihat pada kemampuan akhir yang kemudian terdapat suatu indikator. Indikator pembelajaran yang dikembangkan berdasarkan kemampuan akhir meliputi:Menjelaskan prinsip ekstraksi logam, Menjelaskan sifat fisik kimia unsur $\mathrm{Sc}, \mathrm{Ti}, \mathrm{V}, \mathrm{Cr}, \mathrm{Mn}, \mathrm{Fe}$, $\mathrm{Co}, \mathrm{Ni} \mathrm{Cu}$, dan $\mathrm{Zn}$.

Bagi Mahasiswa yang menempuh kimia anorganik unsur transisi adalah mahasiswa yang baru mendapatkan mata kuliah kimia anorganik ini menganggap bahwa materi unsur adalah materi yang dianggap cukup sulit dikarenakan terlalu banyak teori dan baca-bacaan, serta belum terlalu banyak mengetahui fungsi kegiatan pembelajaran materi unsur transisi.

\section{Tahap Perancangan (design)}

Pada tahap ini, analisis mahasiswa diperoleh berdasarkan hasil observasi yang dilakukan oleh dosen dimana dalam pemahaman materi unsur transisi mahasiswa dianggap sulit dan terkesan merupakan materi yang sifatnya abstrak. Kesulitan pemahaman materi disebabkan adanya aplikasi dan sifat-sifat senyawa transisi yang perlu ada visualisasi melalui video atau gambar.

Berdasarkan analisis konsep dan analisis tugas diperoleh garis besar bahwasannya suatu media pembelajaran dapat dijadikan sarana untuk membantu 
mahasiswa dalam pencapaian kompetensi yang diharapkan dengan menyesuaikan karakteristik mahasiswa yaitu pada umumnya mahasiswa yang menempuh matakuliah kimia anorganik 1 merupakan kaum milenial dimana perkembangan era globalisasi pada abad 21 tersebut terjadi pada sektor teknologi dan komunikasi yang semakin berkembang. Sehingga pembelajaran dengan menggunakan internet atau yang lebih dikenal dengan elearning sangat sekali dibutuhkan dalam menunjang mahasiswa untuk belajar.

Tersedianya fasilitas e-learning/vilearning memungkinkan pembelajar untuk lebih dapat menggunakan waktu dan tempat dalam mengikuti pembelajaran yang tersedia secara online. Teknologi online memberikan kemudahan untuk mahasiswa untuk mendapatkan kelebihan informasi dalam rangka pemenuhan tuntutan kompetensi dan juga pengayaan [7].

Multimedia yang dikembangkan merupakan multimedia interaktif yang berbasis bended learning, sehingga pembelajaran menggunakan multimedia tersebut dapat dilakukan pada saat mahasiswa melakukan pembelajaran secara online. Pembelajaran offline selama perkuliahan tatap muka dengan melakukan kegiatan diskusi secara bersama. Sedangkan untuk pembelajaran secara online diperlukan website dimana dosen dan mahamahasiswa dapat berkomunikasi secara baik. Penggunaan website menggunakan media vi-learning yang telah dimiliki Unesa dimana mahasiswa dan dosen tergabung dalam suatu kelas pembelajaran yaitu kelas mata kuliah kimia anorganik unsur transisi.

\section{Tahap Pengembangan (develop)}

1. Hasil Observasi Aktivitas Mahasiswa

Observasi aktivitas dilakukan dengan cara mengamati setiap kegiatan yang dilakukan oleh mahasiswa yang kaitannya dengan penggunaan media pembelajaran yaitu multimudia interaktif berbasis blended learning. Karena media pembelajaran berbasis blended learning, maka aktivitas yang dilakukan adalah pembelajaran dengan menggabungkan aktivitas online dengan offline.

Aktivitas kegiatan online diamati berdasarkan log activity pada website, sedangkan untuk kegiatan offline dilakukan oleh pengamat. Penilaian dilakukan dengan menggunakan skala Guttman dengan jawaban "Ya" dan "Tidak" untuk pernyataan positif dan negatif. Hasil observasi aktivitas mahasiswa akan dijabarkan berdasarkan tujuan yang merupakan kriteria aktivitas yang dilakukan baik dalam kegiatan online maupun offline disajikan dalam tabel 1.

\section{Tabel 1 Hasil Observasi Aktivitas Mahasiswa}

\begin{tabular}{|c|c|c|c|c|}
\hline \multirow[t]{2}{*}{ No. } & \multirow[t]{2}{*}{ Tujuan } & \multirow[t]{2}{*}{ Aktivitas } & \multicolumn{2}{|c|}{$\begin{array}{c}\text { Jawaban } \\
\text { Ya }\end{array}$} \\
\hline & & & $\sum$ & $\%$ \\
\hline \multicolumn{5}{|c|}{ Pembelajaran On Line } \\
\hline 1. & $\begin{array}{l}\text { Mengetahui } \\
\text { ketertarikan } \\
\text { vi learn }\end{array}$ & $\begin{array}{l}\text { Mahasiswa } \\
\text { melihat } \\
\text { konten vi } \\
\text { learn }\end{array}$ & 42 & 100 \\
\hline 2. & $\begin{array}{l}\text { Mengetahui } \\
\text { semangat } \\
\text { belajar }\end{array}$ & $\begin{array}{l}\text { Mahasiswa } \\
\text { mendownload } \\
\text { multimedia } \\
\text { interaktif }\end{array}$ & 42 & 100 \\
\hline 3. & $\begin{array}{l}\text { Mengetahui } \\
\text { ketertarikan } \\
\text { media }\end{array}$ & $\begin{array}{l}\text { Mahasiswa } \\
\text { mengerjakan } \\
\text { tugas dengan } \\
\text { bantuan } \\
\text { media ajar di } \\
\text { vi learn }\end{array}$ & 42 & 100 \\
\hline 4. & $\begin{array}{l}\text { Mengetahui } \\
\text { semangat } \\
\text { belajar }\end{array}$ & $\begin{array}{l}\text { Mahasiswa } \\
\text { aktif } \\
\text { melakukan } \\
\text { diskusi pada } \\
\text { forum diskusi }\end{array}$ & 42 & 100 \\
\hline \multicolumn{5}{|c|}{ Pembelajaran Off Line } \\
\hline 1. & $\begin{array}{l}\text { Mengetahui } \\
\text { semangat } \\
\text { belajar }\end{array}$ & $\begin{array}{l}\text { Video dan } \\
\text { PPT sebagai } \\
\text { media ajar } \\
\text { untuk } \\
\text { menyelesaika } \\
\text { n tugas }\end{array}$ & 42 & 100 \\
\hline 2. & & $\begin{array}{l}\text { Mahasiswa } \\
\text { aktif dalam } \\
\text { kegiatan } \\
\text { pembelajaran } \\
\text { dan } \\
\text { menyelesaika }\end{array}$ & 42 & 100 \\
\hline
\end{tabular}




\begin{tabular}{|c|c|c|c|c|}
\hline \multirow[b]{2}{*}{3.} & & \multicolumn{3}{|l|}{$\mathrm{n}$ tugas } \\
\hline & & $\begin{array}{l}\text { Mahasiswa } \\
\text { pro-aktif } \\
\text { dalam } \\
\text { mempresenta } \\
\text { sikan hasil } \\
\text { tugas. }\end{array}$ & 42 & 100 \\
\hline 1. & $\begin{array}{l}\text { Mengetahui } \\
\text { ketertarikan } \\
\text { media }\end{array}$ & $\begin{array}{l}\text { Mahasiswa } \\
\text { mengerjakan } \\
\text { tugas } \\
\text { menggunakan } \\
\text { bantuan } \\
\text { multimedia } \\
\text { interaktif }\end{array}$ & 42 & 100 \\
\hline 2. & & $\begin{array}{l}\text { Mahasiswa } \\
\text { dapat } \\
\text { mengoperasik } \\
\text { an dengan } \\
\text { benar } \\
\text { multimedia } \\
\text { interaktif }\end{array}$ & 42 & 100 \\
\hline
\end{tabular}

Dari data yang tersaji pada Tabel 1 dapat diketahui bahwaKetertarikan media dalam hal ini berkaitan dengan media pembelajaran yang dikembangkan yaitu multimedia interaktif berbasis blended learning terhadap proses belajar. Pada kegiatan online, aktivitas yang dilakukan mahasiswa meliputi kegiatan mahasiswa dalam menggunakan multimedia interaktif serta mengerjakan kegiatan pretest di vilearn unesa yang tersedia dalam bentuk quiz. Pengamatan dapat dilakukan melalui $\log$ activity pada website vi-learn Unesa, dimana untuk mahasiswa yang telah melihat multimedia interaktif, maka pada nama kegiatan di log activity bertuliskan "course module viewed" dan mahasiswa telah membuka dan mengerjakan kegiatan Quiz atau test maka bertuliskan "quiz attempt viewed". Hasil analisis log activity terhadap multimedia interaktif bentuk molekul diketahui terdapat 42 orang mahasiswa dari 42 participants yang melaksanakannya atau persentase yang diperoleh adalah 100\%. Hal ini menunjukkan bahwa kriteria media ajar video dan PPT adalah sangat layak.

Pada kegiatan offline dilakukan, aktivitas yang dilakukan yaitu mahasiswa menyelesaikan tugas menggunakan bantuan multimedia interaktif. Dalam hal ini seorang pengamat mengamati kondisi mahasiswa pada saat melakukan kegiatan pembelajaran. Pengamatan yang dilakukan meliputi kegiatan mahasiswa pada saat diberikan penugasan kemudian mahasiswa tersebut melihat dan membaca multimedia interaktif yang telah diunduh dari vi-learn dan multimedia tersebut dijadikan sebagai acuan dalam pengerjaan soal/tugas yang diberikan. Berdasarkan hasil pengamatan yang dilakukan secara mayoritas mahasiswa melihat dan membaca kemudian mendiskusikan terhadap temannya dengan persentase yang diperoleh dalam aktivitas ini adalah 100\%, sehingga kriteria yang diperoleh pada aktivitas ini adalah sangat layak.

Kelebihan multimedia interaktif apabila diterapkan dalam pembelajaran berbasis blended learning diantaranya sistem pembelajaran dapat berlangsung lebih inovatif dan interaktif dimana mahasiswa akan dituntut lebih inovatif dalam suatu pemecahan masalah terobosan pembelajaran dengan menggabungkan teks, gambar, audio, musik, animasi, gambar atau video dalam suatu kesatuan yang akan mendukung tercapainya tujuan pembelajaran yang dibuat. Multimedia interaktif yang dibuat juga dapat menaikkan motivasi dan ketertarikan mahasiswa selama proses pembelajaran sehingga mahasiswa dapat lebih mandiri dalam mendapatkan informasi berkaitan tentang ilmu pengetahuan [8]

Aktivitas dengan tujuan untuk mengetahui semangat belajar meliputi kegiatan pada saat online dan offline. Semangat belajar dalam hal ini berkaitan dengan kegiatan mahasiswa dalam berpartisipasi aktif dikegiatan diskusi pada forum diskusi yang telah disediakan pada website vi-learn unesa danaktivitas lain seperti mahasiswa mendownload materi ajar video dan PPT yang dapat diamati melalui menu log activity pada website vilearn, dimana untuk mahasiswa yang telah 
melihat multimedia interaktif, maka pada nama kegiatan di log activity bertuliskan "modul telah dilihat" dan secara otomatis mahasiswa telah mengunduh materi ajar. Pada aktitivitas ini terdapat 42 orang mahasiswa dari 42 participants yang melaksanakannya. Aktivitas lainnya berupa kegiatan diskusi melalui chat forum. Mahasiswa dibentuk dalam beberapa kelompok, dalam setiap kelompok akan melakukan diskusi berkaitan dengan bentuk molekul yang telah diberikan/ dibuat oleh dosen pengampu pada website vi-learning.

Pada kegiatan offline, aktivitas yang dilakukan dalam menumbuhkan semangat belajar yaitu mahasiswa aktif dalam kegiatan pembelajaran dan menyelesaikan tugas serta mahasiswa pro-aktif dalam mempresentasikan hasil tugas. Hal tersebut dapat dilihat dari giatnya mahasiswa dalam memecahkan permasalahan yang diberikan oleh dosen. Dimana dalam aktivitas ini mahasiswa dibentuk ke dalam satu kelompok, setiap kelompok akan diberikan soal/tugas untuk didiskusikan.

Pembelajaran dengan menggunakan metode pengajaran dan pembelajaran blended learning memungkinkan mahasiswa untuk memperoleh pemahaman yang lebih pada mahasiswa yaitu dengan adanya pembelajaran blended learning dapat membangun persepsi positif dari pengajaran yang diterima sebelumnya, menjelaskan tujuan dan aturan, memberikan mahasiswa dengan tingkat yang lebih tinggi independensi dalam proses pembelajaran [9]. Hal tersebut akan berbeda apabila pembelajaran yang digunakan merupakan aktivitas pembelajaran yang bersifat konvensional menjadikan pembelanajaran terjadi menjadi berkurang interaksinya dengan dosen dan mahasiswa lainnya, penundaan dalam pembelajaran yang tidak bergantung waktu, serta mengurangi motivasi untuk membaca materi pembelajaran secara online.

\section{Hasil Angket Respon Mahasiswa}

Mahasiswa diminta mengisi lembar angket repon untuk mengetahui pendapat mereka mengenai perangkat pembelajaran yang dikembangkan. Tabel 2 menyajikan persentase mahasiswa yang memberikan tanggapan positif (pada kolom "Ya").

\section{Tabel 2 Hasil Angket Respon} Mahasiswa

\begin{tabular}{|c|c|c|c|}
\hline \multicolumn{4}{|c|}{ Pernyataan Positif $(\mathrm{Ya}=1)$} \\
\hline No. & Uraian & $\sum$ & $\%$ \\
\hline 1. & $\begin{array}{l}\text { Perkuliahan berbasis vi } \\
\text { learning merupakan hal } \\
\text { yang baru bagi saya }\end{array}$ & 42 & 100 \\
\hline 2. & $\begin{array}{l}\text { Pembelajaran } \text { dengan } \\
\text { menggunakan media ajar } \\
\text { berbasis vi learning } \\
\text { merupakan hal yang } \\
\text { menarik }\end{array}$ & 42 & 100 \\
\hline 3. & $\begin{array}{l}\text { Pembelajaran } \\
\text { menggunakan media ajar } \\
\text { berbasis vi learning } \\
\text { membantu saya untuk } \\
\text { lebih memahami materi } \\
\text { unsur transisi }\end{array}$ & 42 & 100 \\
\hline 4. & $\begin{array}{l}\text { Saya merasa termotivasi } \\
\text { untuk belajar dengan } \\
\text { menggunakan media ajar } \\
\text { berbasis vi learning }\end{array}$ & 41 & 97,62 \\
\hline 5. & $\begin{array}{l}\text { Pembelajaran dengan } \\
\text { menggunakan media ajar } \\
\text { berbasis vi learning } \\
\text { membuatwaktu belajar } \\
\text { menjadi lebih efisien }\end{array}$ & 42 & 100 \\
\hline \multicolumn{4}{|c|}{ Pernyataan Negatif $($ Tidak $=1$ ) } \\
\hline 1 & $\begin{array}{l}\text { Saya merasa kesulitan } \\
\text { saat menggunakan media } \\
\text { ajar berbasis vi learning }\end{array}$ & 38 & 90,48 \\
\hline 2 & $\begin{array}{l}\text { Media ajar berbasis } v i \\
\text { learning tidak membantu } \\
\text { saya dalam mengulangi } \\
\text { materi pembelajaran }\end{array}$ & 42 & 100 \\
\hline
\end{tabular}

Berdasarkan hasil angket respon mahasiswa pada tabel 2 diketahui sebanyak $100 \%$ mahasiswa beranggapan bahwa media ajar berbasis vi learning merupakan hal yang baru bagi mahasiswa. Selain itu jika dikaitkan dengan materi unsur transisi, sebesar $100 \%$ mahasiswa merasa senang dan merasa terbantu dalam melakukan pemahaman materi apabila pembelajarannya menggunakan media ajar berbasis vi learning 
Secara umum, pembelajaran kimia menekankan pada 3 aspek yaitu makroskopik, mikroskopik, dan simbolik. Representasi dari aspek makroskopis ditunjukkan dengan fenomena-fenomena yang terjadi dalam kehidupan sehari-hari maupun yang dipelajari di laboratorium menjadi suatu yang dapat diamati secara langsung. Aspek mikroskopis direpresentasikan memiliki tingkatan untuk menjelaskan dan menerangkan fenomena yang diamati, sedangkan, aspek simbolik digunakan untuk mewakili fenomena makroskopik [10]. Sehingga penerapan digunakan untuk lebih mendalami keadaan yang berkaitan dengan materi unsur transisi.

Berdasarkan hasil angket respon sebesar $100 \%$ mahasiswa berpendapat pembelajaran dengan menggunakan media ajar berbasis vi learning membuat waktu belajar menjadi lebih efisien. Informasi yang diberikan dalam pembelajaran akan menjadi terasa lebih riil karena multimedia interaktif dapat secara langsung disaksikan oleh mata, visualisasi lebih lengkap karena disajikan dalam bentuk teks, gambar, audio, video, maupun animasi akan lebih diingat dan ditangkap mahasiswa, proses belajar mengajar lebih terkendali, lebih praktis, serta dapat menghemat waktu [8]. Kesimpulan dari penggunaan multimedia interaktif berbasis blended learning ini adalah 100\% mahasiswa setuju dengan anggapan bahwa multimedia interaktif membantu mahasiswa dalam mengulangi materi pembelajaran.

\section{SIMPULAN DAN SARAN}

Berdasarkan beberapa temuan yang telah tersaji maka dapat disimpulkan Materi kuliah Daring Kimia Anorganik Unsur Transisi layak digunakan berdasarkan hasil observasi aktivitas mahasiswa dan angket respon mahasiswa.
Saran yang dapat diberikan berdasarkan hasil penelitian adalah mengoptimalkan kegiatan forum diskusi agar lebih membantu kegiatan vi learn mata kuliah Kimia Anorganik Unsur Transisi.

\section{UCAPAN TERMAKASIH}

Terima kasih kepada Rektor Unesa yang telah mendanai penelitian ini melalui program penelitian hibah vi-learn 2018.

\section{DAFTAR PUSTAKA}

1. Gabel, Dorothy. 1999. Improving Teaching and Learning through Chemistry Education Research: A Look to the Future. Journal of Chemistry Education Vol. 76 No. 4

2. Yendri, Dodon. 2011. Blended Learning: Model Pembelajaran Kombinasi E-learning dalam Pendidikan Jarak Jauh. http://fti.unand.ac.id/images/BlendedLearning .pdf (diakses pada tanggal 30 November 2016)

3. Rahmana, A.Y \& Endang Susantini. 2015. "Validitas Perangkat Pembelajaran Blended learning Terintregrasi Edmodo Pada Sub Materi Katabolisme Karbohidrat". Unesa Journal of Biologi Education. Vol. 4 No. 2

4. Ibrahim, Muslimin dan Wahyusukartiningsih. 2014. Model Pembelajaran Inovatif Melalui Pemaknaan. Surabaya: Unesa University Press.

5. Riduwan. 2015. Skala Pengukuran VariabelVariabel Penelitian. Bandung: Alfabeta

6. Slavin, R.E. 2008. Educational Psychology Theory and Practice. Fifth Edition. Boston: Allyn and Bacon.

7. Husamah. 2014. Pembelajaran Bauran (Blended Learning). Jakarta: Prestasi Pustaka

8. Murniati, D.R \& Sanjaya, I G.M. 2013. "Pengembangan Perangkat Pembelajaran Kimia Berbasis Blended Learning di SMA Negeri 7 Kediri". Unesa Journal of Chemical Education. Vol. 2 No. 3

9. López-Pérez et all. 2011. Blended Learning in Higher Education: Students` perceptions and their relation to outcomes. Computers and Education Vol. 56 No. 3

10. Laneri et all. 2016. Effects of Long-Term Mindfulness Meditation on Brain's White Matter Microstructure and its Aging. Front Aging Neurosci 